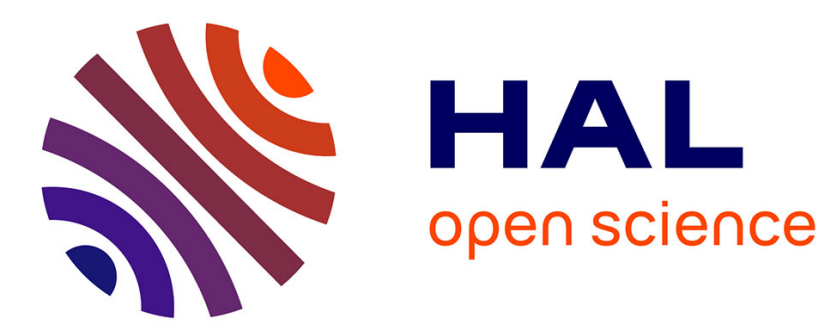

\title{
Organometallic Antitumor Compounds: Ferrocifens as Precursors to Quinone Methides
}

Yong Wang, Pascal Pigeon, Siden Top, Michael J. Mcglinchey, Gérard Jaouen

\section{To cite this version:}

Yong Wang, Pascal Pigeon, Siden Top, Michael J. Mcglinchey, Gérard Jaouen. Organometallic Antitumor Compounds: Ferrocifens as Precursors to Quinone Methides. Angewandte Chemie International Edition, 2015, 54 (35), pp.10230-10233. 10.1002/anie.201503048 . hal-01230371

\section{HAL Id: hal-01230371 \\ https://hal.science/hal-01230371}

Submitted on 15 Jul 2016

HAL is a multi-disciplinary open access archive for the deposit and dissemination of scientific research documents, whether they are published or not. The documents may come from teaching and research institutions in France or abroad, or from public or private research centers.
L'archive ouverte pluridisciplinaire HAL, est destinée au dépôt et à la diffusion de documents scientifiques de niveau recherche, publiés ou non, émanant des établissements d'enseignement et de recherche français ou étrangers, des laboratoires publics ou privés. 
Angew. Chem. Int. Ed., 2015, 54, 10230-10233

Angew. Chem., 2015, 127, 10368-10371

\title{
Organometallic Antitumor Compounds: Ferrocifens as Precursors to Quinone Methides
}

Yong Wang, Pascal Pigeon, Siden Top,* Michael J. McGlinchey, and G'rard Jaouen*

[*] Dr. Y. Wang, Dr. P. Pigeon, Dr. S. Top, Prof. G. Jaouen

Sorbonne Universités, UPMC Univ Paris 06, UMR 8232, IPCM, F-75005 Paris, France

CNRS, UMR 8232, IPCM, F-75005 Paris, France

PSL, Chimie ParisTech, 11 rue Pierre et Marie Curie, F-75005 Paris, France

E-mail: gerard.jaouen@chimie-paristech.fr, siden.top@chimie-paristech.fr

$\left[{ }^{* *}\right.$ Prof. Michael J. McGlinchey

UCD School of Chemistry and Chemical Biology

University College Dublin, Belfield, Dublin 4 (Ireland)

\begin{abstract}
The synthesis and chemical oxidation profile of a new generation of ferrocifen derivatives with strong antiproliferative behavior in vitro is reported. In particular, the hydroxypropyl derivative $\mathrm{HO}\left(\mathrm{CH}_{2}\right)_{3} \mathrm{C}(\mathrm{Fc})=\mathrm{C}\left(\mathrm{C}_{6} \mathrm{H}_{4} \mathrm{OH}\right)_{2}, 3 \boldsymbol{b}$, exhibited exceptional antiproliferative activity against HepG2 and MDA-MB-231 TNBC cells with $I C_{50}$ values of 0.07 and $0.11 \mu \mathrm{M}$ respectively. Chemical oxidation of $\mathbf{3 b}$ yielded an unprecedented tetrahydrofuran-substituted quinone methide $(Q M)$ via internal cyclization of the hydroxy-alkyl chain, whereas the corresponding alkyl analog $\mathrm{CH}_{3} \mathrm{CH}_{2}-\mathrm{C}(\mathrm{FC})=\mathrm{C}\left(\mathrm{C}_{6} \mathrm{H}_{4} \mathrm{OH}\right)_{2}$ merely formed a vinyl QM. The ferrocenyl group in $\mathbf{3 b}$ plays a key role not only as an intramolecular reversible redox "antenna" but also as a stabilized carbenium ion "modulator". The presence of the oxygen heterocycle in $\mathbf{3 b - Q M}$ enhances its stability and leads to a unique chemical oxidation profile, thus revealing crucial clues towards deciphering its mechanism of action in vivo.
\end{abstract}


In the search for antitumor organometallics with behavior differentiated from the primary targeting of DNA, an approach based on common metals such as $\mathrm{Fe}$ has already proved of interest. ${ }^{[1]}$ Many ferrocenyl species showing contrasting antiproliferative effects, ${ }^{[2]}$ in particular the family of acyclic or ansa ferrocifens (Chart 1 ) are seen as innovative drug candidates. ${ }^{[3]}$ At low concentrations they operate principally via a mechanism of senescence, ${ }^{[4]}$ although in some cases apoptosis is possible ${ }^{[4 a]}$ through at least partially targeting enzymes of a redox system, for example, thioredoxin reductase $(\operatorname{TrxR}){ }^{[5]}$ that are over expressed in cancer cells, while leaving healthy cells untouched. ${ }^{[3 \mathrm{c}, 3 \mathrm{~d}]}$ They possess $\mathrm{IC}_{50}$ values around $0.6 \mu \mathrm{M}$ for acyclic systems to $0.09 \mu \mathrm{M}$ for ansa molecules with triplenegative MDA-MB-231 cancer cells, and have been formulated for in vivo studies on breast and glioma. ${ }^{[3 d, 6]}$ These products are of great potential interest since senescence could be an alternative route for cancers resistant to proapoptotic stimuli, which play a major role in the incidence of mortality due to this type of pathology. ${ }^{[4 b]}$

Ideally, to allow the establishment of a new mechanism of action, a new generation of products is required. These products should involve an unequivocally characterized primary metabolite and they must also exhibit lower $\mathrm{IC}_{50}$ values than those of the acyclic series. Previously, the molecules in Figure 1 were modified by changing metals and functional groups, and attaching various chains. ${ }^{[7]}$ With replacement of the alkyl chain by a hydroxypropyl group, we present the first observations on what may become a new generation of ferrocifen derivatives (Figure 2A) with strong antiproliferative potential. Moreover, they yielded a novel quinone methide (QM) that is key to new behavior.

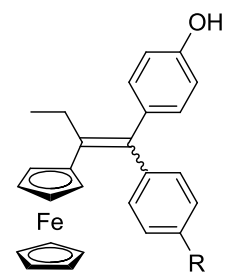

acyclic series (1)

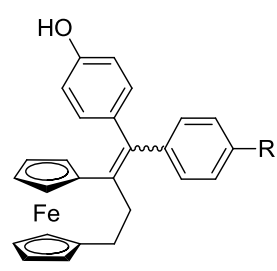

ansa series

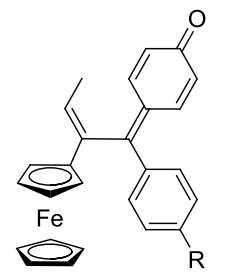

acyclic QM (1-QM)

Figure 1. Acyclic and ansa organometallic compounds derived from the ferrocifen family $(\mathrm{R}=\mathrm{H}$ or $\mathrm{OH})$, and the key acyclic quinone methide (QM).

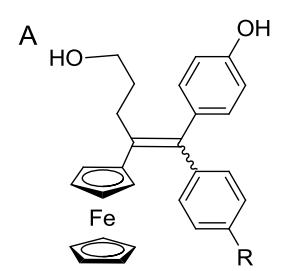

3, hydroxypropyl series
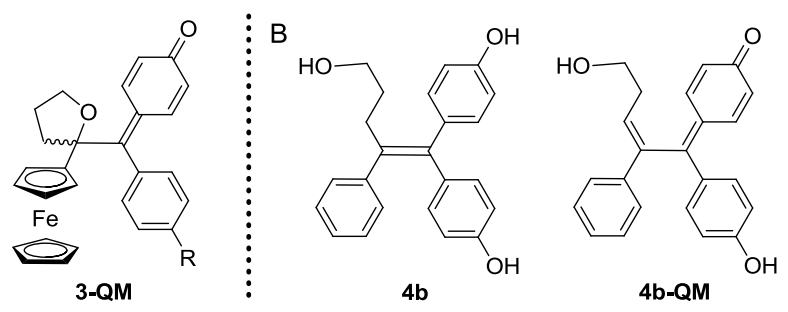

Figure 2. A) The new hydroxypropyl series, 3, derived from the acyclic ferrocifen family, and the novel

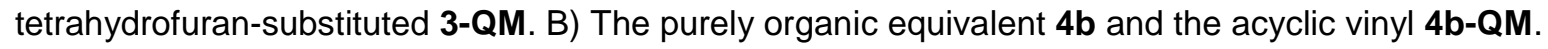




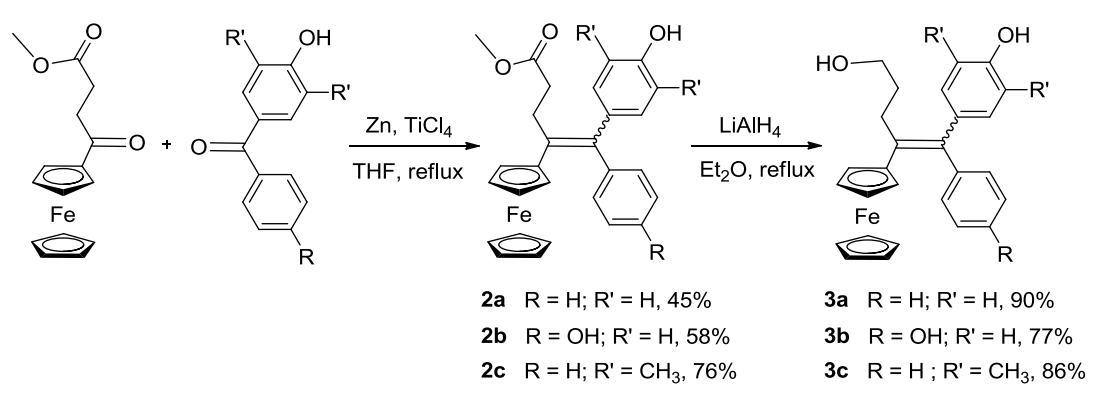

Scheme 1. Syntheses of the ferrocenyl compounds in series 2 and $\mathbf{3}$.

Efficient syntheses of the desired hydroxypropyl-alkenes, 3, proceeded via McMurry crosscoupling ${ }^{[8]}$ to give compounds $2 \mathrm{a}-\mathrm{c}$ and $\mathrm{LiAlH}_{4}$ reduction of the esters to the corresponding alcohols 3 (Scheme 1). Monophenol analogs 2a, 2c, 3a, and 3c were obtained as mixtures of $Z$ and $E$ isomers. The corresponding tamoxifen organic derivatives (series 4) were prepared analogously. X-ray crystal structures of $\mathbf{3 a}$ and $\mathbf{3 b}$ are shown in Figure $\mathbf{S} 1$ in the Supporting Information.

Lipophilicity values and antiproliferative effects against the estrogen-receptor-negative (ER-) MDAMB-231 breast cancer cells are reported in Table 1, together with the values obtained for the acyclicdiphenol compound, $\mathrm{Fc}(\mathrm{Et}) \mathrm{C}=\mathrm{C}\left(\mathrm{C}_{6} \mathrm{H}_{4} \mathrm{OH}\right)_{2}$. Compared to the organic compound, $\mathbf{4 b}$, the ferrocenyl moiety increases the lipophilicity of the new molecules, while the presence of polar groups decreases their lipophilicity. Compound $\mathbf{3 b}$ shows an exceptional antiproliferative effect on the hormoneindependent MDA-MB-231 cell line with an $\mathrm{IC}_{50}$ value around $0.11 \mu \mathrm{M}$, which is markedly superior to that of its ester precursor $\mathbf{2 b}$ and to the acyclic diphenol compound. The tamoxifen derivative $\mathbf{4 b}$, the organic analogue of $\mathbf{3 b}$, shows limited cytotoxicity against MDA-MB-231 $\left(\mathrm{IC}_{50} \approx 50 \mu \mathrm{M}\right)$, a result that underlines the key role played by the ferrocenyl substituent in the generation of antiproliferative effects; tamoxifen itself has an $\mathrm{IC}_{50}$ value of $40 \mu \mathrm{M}$. ${ }^{[9]}$

Table 1. $I_{50}$ values with MDA-MB-231 and log Po/w results for selected ferrocenyl compounds

\begin{tabular}{ccc}
\hline Compound & $\mathrm{IC}_{50}(\mu \mathrm{M})^{\mathrm{a}}$ & $\log \mathrm{Po} / \mathrm{w}$ \\
\hline $\mathbf{1}(\mathrm{R}=\mathrm{OH})^{\mathrm{b}}$ & $0.64 \pm 0.06$ & 5.0 \\
$\mathbf{4 b}$ & $50.78 \pm 1.33$ & 3.6 \\
$\mathbf{2 a}$ & $4.09 \pm 1.67$ & $5.0 / 5.3$ \\
$\mathbf{2 b}$ & $0.44 \pm 0.09$ & 4.4 \\
$\mathbf{2 c}$ & $1.50 \pm 0.17$ & $5.4 / 6.2$ \\
3a & $1.16 \pm 0.02$ & $4.5 / 4.9$ \\
3b & $0.11 \pm 0.02$ & 4.2 \\
3c & $1.23 \pm 0.05$ & $5.0 / 5.6$
\end{tabular}

${ }^{\text {a }}$ Measured after 5 days of culture (mean of two independent experiments \pm SD). ${ }^{\text {b }}$ Values from ref. [1a].

Compound $\mathbf{3 b}$ was selected for further tests on human tumor cell lines, which revealed that it could prevent the growth of pancreatic carcinoma cell Mia-PaCa with an $\mathrm{IC}_{50}$ value of $1.23 \mu \mathrm{M}$ and shows excellent antiproliferative activity against liver hepatocellular carcinoma with an $\mathrm{IC}_{50}$ value of $0.07 \mu \mathrm{M}$ 
on HepG2 cells. This exceptional antiproliferative behavior led to further exploration of its framework to try to decipher the active motif.

We find that 1-QM (Figure 1) are the key metabolites upon metabolism of the acyclic alkyl chain series 1 by rat liver microsomes and can also be prepared via chemical oxidation. ${ }^{[3-f]}$ To help unravel the reasons for the excellent antiproliferative effect of $\mathbf{3 b}$, chemical oxidation was used to prepare selected putative metabolites (Scheme 2). NMR and X-ray data confirmed their structures as novel tetrahydrofuran-substituted 3-QM systems, involving cyclization of the hydroxyalkyl chain rather than the previously reported behavior of acyclic 1-QM which contains a conjugated trans double bond. ${ }^{[3 \mathrm{e}]}$

The QM structure of 3c-QM was established by X-ray (Figure 3) and the cyclic ether confirms the intramolecular reaction of the hydroxyl function on the carbon adjacent to the ferrocenyl group.

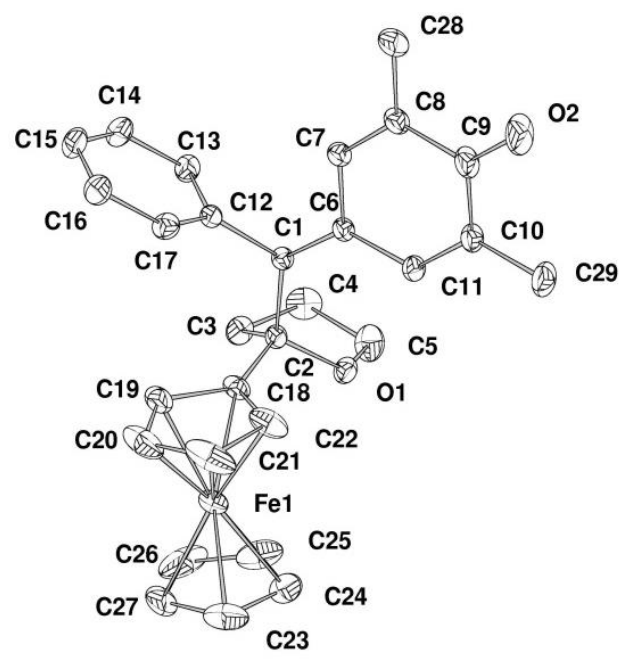

Figure 3. Molecular structure of 3c-QM with thermal ellipsoids shown at 50\% proability.

For the diphenol $1(\mathrm{R}=\mathrm{OH})$, an archetypical example of the first generation of ferrocifen acyclic species (Figure 1), the corresponding QM proved to be quite unstable and exhibited evidence of decomposition before oxidation was complete. In contrast, $\mathbf{3 b} \mathbf{b} \mathbf{Q M}$ derived from the hydroxypropyldiphenol precursor showed reasonable stability, at least 4 weeks when kept at $-20{ }^{\circ} \mathrm{C}$ in the solid state. Moreover, its stability in solution was also significantly improved (Figures S2-S3), except in the weakly acidic solvent chloroform in which it started to decompose. The half-life in acetone was approximately $30 \mathrm{~h}$, but was even longer in DMSO where it remained unchanged for at least two days with a half-life of around six weeks.

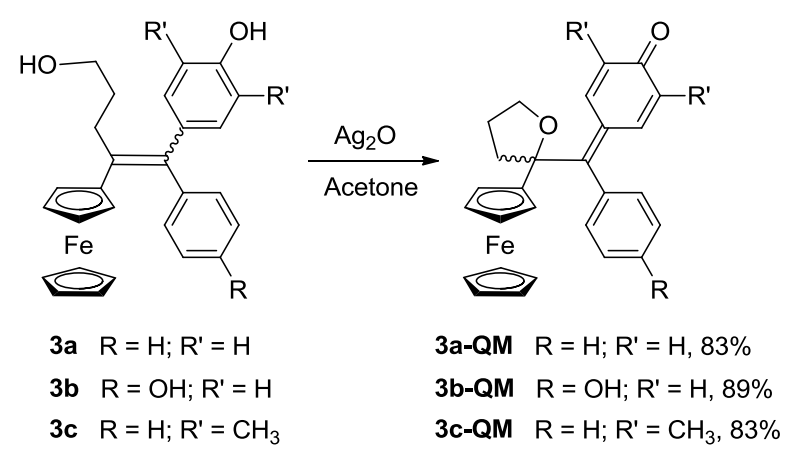

Scheme 2. Synthesis of the quinone methides. 
The formation of the quinone ring was entirely consistent with the mechanism already proposed for acyclic species, whereby the ferrocenyl unit acts as a kind of intramolecular oxidation "antenna" such that oxidation of the phenol group leads to a carbenium ion. ${ }^{[10]}$ However, from this point the process can vary owing to the presence of the terminal hydroxyl function, such that the carbenium ion undergoes nucleophilic attack to form a heterocycle rather than a double bond (Scheme 3). Oxidation of compounds 4 , the purely organic analogues of the ferrocenyl alcohol derivatives $\mathbf{3}$ yielded only the acyclic vinyl QM systems (Chart 2B). The absence of a significant NMR peak between 3.5 and 4.5 ppm, which is characteristic of $\mathrm{OCH}_{2}$ in a tetrahydrofuran ring, indicated that oxidation of 4 did not yield a QM heterocycle. NMR peaks characteristic of the acyclic QM appeared transiently, but decomposition prior to complete oxidation prevented isolation of the $\mathrm{QM}$, even for compound $\mathbf{4 c}$ in which the ferrocenyl group of $3 \mathrm{c}$ was replaced by phenyl group. Thus, for the organic analogue, $\mathbf{4}$, oxidation predominantly gives the vinyl $\mathrm{QM}$, whereas in the ferrocenyl series, 3, oxidation furnishes the novel QM that bears a tetrahydrofuran ring. These quite distinct results, together with the well-known fact that organometallic complexes adjacent to a double bond favor the stabilization of $\alpha$-carbenium ions, let us deduce that the ferrocenyl group not only plays the role of intramolecular oxidation "antenna" but also acts as a "modulator" and facilitates trapping of the hydroxyl function by the carbenium ion, thereby leading to tetrahydrofuran ring formation. To the best of our knowledge, the 3QM species is the first tetrahydrofuran-substituted QM, which may indicate the potential for structural diversity in quinone chemistry.

Freshly synthesized $\mathbf{3 a - Q M}, \mathbf{3 b}-\mathbf{Q M}$ and $\mathbf{3 c}-\mathbf{Q M}$ were also cytotoxic against MDA-MB-231 cells $\left(\mathrm{IC}_{50}\right.$ values of $1.89,4.39$ and $6.00 \mu \mathrm{M}$, respectively). The $\mathrm{IC}_{50}$ values of stable $\mathbf{3 a - Q M}$ and $\mathbf{3 c} \mathbf{c}-\mathbf{Q M}$ were the same as those of their parent molecules $\mathbf{3 a}$ and $\mathbf{3 c}$. The higher value for $\mathbf{3 b} \mathbf{b} \mathbf{Q M}$, relative to $\mathbf{3 b}$, could be due to its relatively better chemical reactivity, since strong nucleophiles may be present in the incubation medium. Nevertheless, this behavior suggests that $\mathbf{3 b}$ should have remarkable intrinsic antiproliferative properties and motivated us to explore the chemical oxidation profiles of $\mathbf{3} \mathbf{b}$ and $\mathbf{3} \mathbf{b}$ QM.

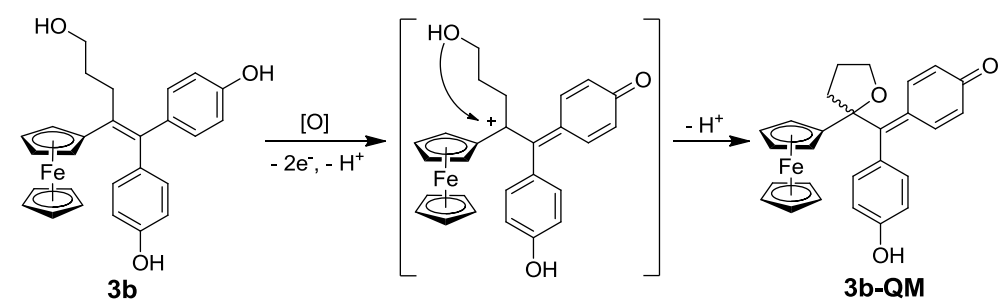

Scheme 3. Proposed mechanism for the formation of the novel heterocyclic ferrocenyl QM species.

The oxidative evolution of $\mathbf{3 b - Q M}$ is more complex than that of $\mathbf{1 - Q M}$ (Scheme 4). ${ }^{[3 e, 5]}$ Its half-life in acetone was around $30 \mathrm{~h}$, and all its derivatives were stable enough to be isolable upon complete decomposition. The four products, $\mathbf{3} \mathbf{b}-\mathbf{A}, \mathbf{3} \mathbf{b}-\mathbf{B}, \mathbf{3} \mathbf{b}-\mathbf{C}$ and $\mathbf{3 b} \mathbf{b}$, which had not previously observed in the metabolic processes of the 1-QM series, ${ }^{[5]}$ were identified by NMR or X-ray (3b-A, Figure S1). For the acyclic ferrocifen derivatives, the major byproduct in each case, during or after oxidation, was an indene product resulting from acid-mediated cyclization, ${ }^{[3 \mathrm{e}, 5]}$ but the presence of the tetrahydrofuran ring leads to different species resulting from involvement of the oxygen atom of the alkyl chain. 


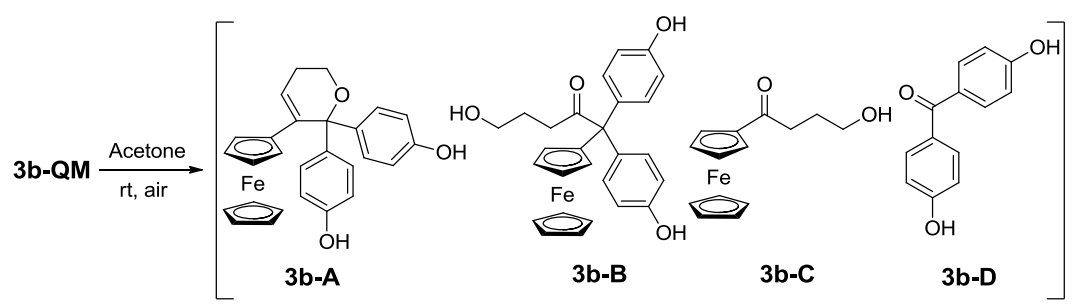

Scheme 4. Metabolic Stability Profile of 3b-QM.

As shown in Scheme S1, under the slightly acidic conditions in acetone, protonation of the quinone $\mathbf{3 b}$-QM can form a carbenium ion that evolves through several pathways. The first is ring expansion by migration of the adjacent oxygen, which places the carbocation adjacent to the ferrocenyl group; and subsequent proton loss to yield $\mathbf{3 b} \mathbf{b}-\mathbf{A}$; secondly, a pinacol rearrangement can give compound $\mathbf{3 b} \mathbf{B}-\mathbf{B}$. $^{[1]}$ Finally, the carbenium ion can react with traces of water giving a pinacol-type intermediate that gives $\mathbf{3 b}-\mathbf{C}$ and $\mathbf{3 b}-\mathbf{D}$ on further oxidation. This radical oxidation parallels a previous report on [3]ferrocenophane derivatives. ${ }^{[11]}$

The cytotoxicity of $\mathbf{3 b} \mathbf{b}-\mathbf{Q M}$ against MDA-MB-231 cells was consistent with its chemical derivatives $\mathbf{3 b}-\mathbf{A}$ and $\mathbf{3 b}-\mathbf{B}$ ( $\mathrm{IC}_{50}$ values of 2.03 and $4.14 \mu \mathrm{M}$, respectively). Compounds $\mathbf{3 b}-\mathbf{Q M}, \mathbf{3 b}-\mathbf{A}, \mathbf{3 b}-\mathbf{B}, \mathbf{3 b}-\mathbf{C}$ and $\mathbf{3 b} \mathbf{b} \mathbf{D}$ were the major products during the chemical oxidation and subsequent decomposition of $\mathbf{3 b}$. The cytotoxic values obtained from the precursor $\mathbf{3 b}$ strongly suggest that, when incubated with live cancer cells, $\mathbf{3 b}$ should generate a remarkable intrinsically electrophilic metabolite which is probably native $\mathbf{3 b} \mathbf{b}-\mathbf{Q M}$. The evolution of $\mathbf{3} \mathbf{b}$ proposed above occurred via chemical methods without the involvement of other nucleophiles. It provides some clues that prodrug $\mathbf{3 b}$ could generate several possible carbenium ions in vivo which could be captured by nucleophiles, such as thiols or selenols, inside the cells. ${ }^{[5]}$ Thus possible cross-coupling with reactive nucleophiles or a related protein can lead to cell death. Another pathway could be relevant to cytotoxicity is oxidative cleavage of pinacol-type analogues..$^{[11]}$

In summary, modification of the alkyl chain in the original acyclic derivatives, yielded $\mathbf{3 b}$, which bears a terminal hydroxy-alkyl group and exhibits exceptional antiproliferative activity against liver hepatocellular carcinoma cells (HepG2) and ER- breast cancer cells (MDA-MB-231) with $\mathrm{IC}_{50}$ values of 0.07 and $0.11 \mu \mathrm{M}$ respectively. Chemical oxidation of $\mathbf{3 b}$ yielded an unprecedented tetrahydrofuransubstituted QM via internal cyclization of the alkyl chain, identified as a possible key primary metabolite. The ferrocenyl group not only plays the role of intramolecular reversible redox "antenna" but also acts as a stabilized carbenium ion "modulator". Resulting from these structural changes, $\mathbf{3 b}$ QM exhibits moderate stability and a unique chemical oxidation profile, revealing crucial clues that may help us decipher its mechanism of action in vivo. Future work will focus on gaining insight into the mechanism of action of these novel species, especially in the presence of healthy cells and selected nucleophiles, thus opening the way to a new generation of unique potential drug candidates.

Keywords: antitumor agents, drug discovery, ferrocene, metabolism, quinones

[1] a) E. Hillard, A. Vessieres, G. Jaouen, in Medicinal Organometallic Chemistry, Vol. 32 (Eds.: G. Jaouen, N. Metzler-Nolte), Topics in Organometallic Chemistry, Springer, 2010, pp. 81-117; b) S. S. Braga, A. M. S. Silva, Organometallics 2013, 32, 5626-5639.

[2] a) S. B. Deepthi, R. Trivedi, L. Giribabu, B. Sridhar, P. Sujitha, C. G. Kumar, J. Organomet. Chem. 2014, 774, 26-34; b) M. Librizzi, A. Longo, R. Chiarelli, J. Amin, J. Spencer, C. Luparello, Chem. 
Res. Toxicol. 2012, 25, 2608-2616; c) A. G. Harry, W. E. Butler, J. C. Manton, M. T. Pryce, N. O'Donovan, J. Crown, D. K. Rai, P. T. M. Kenny, J. Organomet. Chem. 2014, 766, 1-12; d) B. Balaji, B. Balakrishnan, S. Perumalla, A. A. Karande, A. R. Chakravarty, European Journal of Medicinal Chemistry 2014, 85, 458-467; e) J. d. J. Cazares-Marinero, S. Top, A. Vessieres, G. Jaouen, Dalton Trans. 2014, 43, 817-830; f) P. Marzenell, H. Hagen, L. Sellner, T. Zenz, R. Grinyte, V. Pavlov, S. Daum, A. Mokhir, J. Med. Chem. 2013, 56, 6935-6944.

[3] a) D. Plazuk, A. Vessieres, E. A. Hillard, O. Buriez, E. Labbe, P. Pigeon, M. A. Plamont, C. Amatore, J. Zakrzewski, G. Jaouen, J. Med. Chem. 2009, 52, 4964-4967; b) M. Gormen, P. Pigeon, S. Top, E. A. Hillard, M. Huche, C. G. Hartinger, F. de Montigny, M. A. Plamont, A. Vessieres, G. Jaouen, ChemMedChem 2010, 5, 2039-2050; c) Q. Michard, G. Jaouen, A. Vessieres, B. A. Bernard, J. Inorg. Biochem. 2008, 102, 1980-1985; d) E. Allard, C. Passirani, E. Garcion, P. Pigeon, A. Vessieres, G. Jaouen, J. P. Benoit, J. Control. Release 2008, 130, 146153; e) D. Hamels, P. M. Dansette, E. A. Hillard, S. Top, A. Vessieres, P. Herson, G. Jaouen, D. Mansuy, Angew. Chem. Int. Ed. 2009, 48, 9124-9126. f) M.-A. Richard, D. Hamels, P. Pigeon, S. Top, P. M. Dansette, H. Z. S. Lee, A. Vessières, D. Mansuy, G. Jaouen, ChemMedChem. 2015, 10, 981-990.

[4] a) A. Vessières, C. Corbet, J. M. Heldt, N. Lories, N. Jouy, I. Laios, G. Leclercq, G. Jaouen, R. A. Toillon, J. Inorg. Biochem. 2010, 104, 503-511; b) C. Bruyere, V. Mathieu, A. Vessières, P. Pigeon, S. Top, G. Jaouen, R. Kiss, J. Inorg. Biochem. 2014, 141, 144-151.

[5] A. Citta, A. Folda, A. Bindoli, P. Pigeon, S. Top, A. Vessieres, M. Salmain, G. Jaouen, M. P. Rigobello, J. Med. Chem. 2014, 57, 8849-8859.

[6] a) A. L. Lainé, E. Adriaenssens, A. Vessieres, G. Jaouen, C. Corbet, E. Desruelles, P. Pigeon, R. A. Toillon, C. Passirani, Biomaterials 2013, 34, 6949-6956; b) A. L. Lainé, A. Clavreul, A. Rousseau, C. Tétaud, A. Vessieres, E. Garcion, G. Jaouen, R. A. Toillon, C. Passirani, Nanomedicine: NBM 2014, 10, 1667-1677.

[7] G. Jaouen, S. Top, in Advances in Organometallic Chemistry and Catalysis (Ed.: A. J. L. Pombeiro), Wiley, Hodoken, 2014, pp. 563-580.

[8] P. Pigeon, M. Gormen, K. Kowalski, H. Mueller-Bunz, M. J. McGlinchey, S. Top, G. Jaouen, Molecules 2014, 19, 10350-10369.

[9] S. Groleau, J. Nault, M. Lepage, M. Couture, N. Dallaire, G. Bérubé, R. C. Gaudreault. Bioorg. Chem 1999, 27, 383-394.

[10] P. Messina, E. Labbe, O. Buriez, E. A. Hillard, A. Vessieres, D. Hamels, S. Top, G. Jaouen, Y. M. Frapart, D. Mansuy, C. Amatore, Chem. Eur. J. 2012, 18, 6581-6587.

[11] M. Gormen, P. Pigeon, E. A. Hillard, A. Vessieres, M. Huche, M. A. Richard, M. J. McGlinchey, S. Top, G. Jaouen, Organometallics 2012, 31, 5856-5866. 
COMMUNICATION

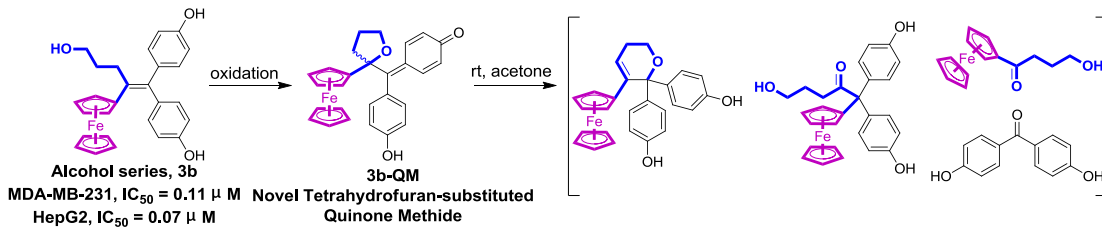

Bifunctional role of ferrocenyl as both intramolecular reversible redox "antenna" and stabilized carbenium ion "modulator" encouraged the oxidation of 3b toward an unprecedented tetrahydrofuran-substituted QM via an internal cyclization of the hydroxyalkyl chain. Subsequent chemical metabolic profile reveals crucial clues that may help us to decipher the mechanism of action for exceptional antiproliferative activity of $\mathbf{3 b}$.

Yong Wang, Pascal Pigeon, Siden Top, ${ }^{*}$ Michael J. McGlinchey, and Gérard Jaouen* Page No. - Page No.

Organometallic Antitumor Compounds: Ferrocifens as Precursors to Quinone Methides 